\title{
Increased Cyclic Guanosine Monophosphate Production and Overexpression of Atrial Natriuretic Peptide A-Receptor mRNA in Spontaneously Hypertensive Rats
}

\author{
Johanne Tremblay, Céline Huot, Roland C. Willenbrock, Francis Bayard, Francis Gossard, Nobuaki Fujio, \\ Caroline Koch, Otto Kuchel, * Waldemar Debinski, and Pavel Hamet \\ Centre de Recherche Hôtel-Dieu de Montréal, Université de Montréal, Montréal, Québec H2W 1T8, Canada, \\ and *Institut de Recherches Cliniques de Montréal, Montréal, Québec H2W 1R7, Canada
}

\begin{abstract}
Atrial natriuretic peptide (ANP) specifically stimulates particulate guanylate cyclase, and cyclic guanosine monophosphate (cGMP) has been recognized as its second messenger. Spontaneously hypertensive rats (SHR) have elevated plasma ANP levels, but manifest an exaggerated natriuretic and diuretic response to exogenous ANP when compared to normotensive strains. In isolated glomeruli, the maximal cGMP response to ANP corresponds to a 12- to 14-fold increase over basal levels in normotensive strains (Wistar 13 \pm 2 ; Wistar-Kyoto 12 \pm 2 ; Sprague-Dawley $14 \pm 2$ ) while a maximal $33 \pm 3$-fold elevation occurs in SHR $(P<0.001)$. This hyperresponsiveness of cGMP is reproducible in intact glomeruli from SHR from various commercial sources. Furthermore, this abnormality develops early in life, even before hypertension is clearly established, and persists despite pharmacological modulation of blood pressure, indicating that it is a primary event in hypertension.
\end{abstract}

In vitro studies have revealed a higher particulate guanylate cyclase activity in membranes from glomeruli and other tissues from SHR. This increase is not accounted for by different patterns of ANP binding to its receptor subtypes between normotensive and hypertensive strains, as assessed by competitive displacement with C-ANP ${ }^{102-121}$, an analog which selectively binds to one ANP receptor subtype. The hyperactivity of particulate guanylate cyclase in SHR and its behavior under basal, ligand (ANP), and detergent-enhanced conditions could be attributed either to increased expression or augmented sensitivity of the enzyme. Radiation-inactivation analysis does not evoke a disturbance in the size of regulatory elements normally repressing enzymatic activity, while the expression of particulate guanylate cyclase gene using mutated standard of A- and B-receptors partial cDNAs, quantified by polymerase chain reaction (PCR) transcript titration assay, manifests a selective increase of one guanylate cyclase subtype. Our data suggest that in hypertension, genetic overexpression of the ANP A-receptor subtype is related to the exaggerated biological response to ANP in this disease. (J. Clin. Invest. 1993. 92:2499-2508.) Key words: Glomeruli • atrial natriuretic peptide $\cdot$ guanylate

Address correspondence to Dr. Johanne Tremblay, Centre de Recherche Hôtel-Dieu de Montréal, 3850 Saint-Urbain Street, Marie-dela-Ferre Pav., Montréal, Québec, Canada H2W 1 T8. 1993

Received for publication 12 August 1992 and in revised form 3 June

J. Clin. Invest.

(c) The American Society for Clinical Investigation, Inc. $0021-9738 / 93 / 11 / 2499 / 10 \quad \$ 2.00$

Volume 92, November 1993, 2499-2508 cyclase - spontaneously hypertensive rats - cyclic guanosine monophosphate $\bullet$ quantitative polymerase chain reaction

\section{Introduction}

Atrial natriuretic peptide (ANP), ${ }^{1}$ a hormone synthesized in specific granules of the heart, elicits multiple physiological responses apparently mediated via cyclic GMP (cGMP; for review, see references 1-5). Some of its most striking biological effects are the natriuresis and diuresis it produces. Despite numerous investigations of its renal mechanisms of action, the exact processes involved are still not fully understood. High concentrations of particulate guanylate cyclase and cGMP levels elevated by ANP have been noted in glomeruli (6-9), which possess an abundance of specific ANP receptors (6, 10-14).

The existence of distinct ANP binding sites has been demonstrated (15-17). The larger (130-kD) ANP receptor type is a glycoprotein linked to particulate guanylate cyclase with rigorous binding specificity (18-21). Isolation, sequencing, cloning, and expression of the protein from various species have shown that guanylate cyclase is an integral part of the molecule (22$25)$. Two subtypes of guanylate cyclase-related receptors (ANP-A and ANP-B receptors) have been cloned with different ligand binding affinities despite overall structural homology $(24,26,27)$. Elucidation of the gene structure of the ANP A-receptor, responding preferentially to ANP, has been achieved (28). Both receptor subtypes have a large extracellular $\mathrm{NH}_{2}$-terminal domain, a putative single membrane spanning sequence and an intracellular region containing both a putative kinase-like regulatory domain required for signalling via ANP (29), and a guanylate cyclase catalytic domain (24, 25 ) responsible for synthesis of cGMP, the effector of ANP. Another receptor type, known as the C-receptor, has a molecular mass of $120 \mathrm{kD}$ on SDS-PAGE and can be reduced to $65 \mathrm{kD}$ with $\beta$-mercaptoethanol (30). It has a high affinity for the ligand and is widely distributed (30). This truncated homodimeric glycoprotein has only 37 amino acids for its intracellular domain (30) and is therefore not linked to catalytic guanylate cyclase activity $(20,30)$. Its role as a clearance or buffer receptor $(31)$ is closely related to internalization of the receptor-ligand complex, recycling and hydrolyzing ANP (32). However, the down-regulation of ANP receptors may require prior ANPguanylate cyclase receptor occupancy (33).

ANP has been postulated to play a role in the development of arterial hypertension and in the counterregulation of increased blood pressure. There are many reports of elevated plasma ANP levels in human essential hypertension (34-38), even in correlation with the extent of left ventricular and auri-

1. Abbreviations used in this paper: ANP, atrial natriuretic peptide; SHR, spontaneously hypertensive rats. 
cular abnormalities (39), and also in healthy young people with a family history of hypertension as well as in SHR (4044). Plasma ANP levels have been reported to be increased in different forms of experimental hypertension (45-48). However, some authors have not found elevated ANP levels in patients with mild, age-adjusted hypertension (49-51) or in young SHR (52).

Down-regulation of ANP receptors has been reported in vitro in vessels as well as in cultured smooth muscle cells, contrasting with normal or even increased cGMP production (53$57)$. No difference in receptor density or affinity is observed in glomeruli of young SHR $(58,59)$, while older animals with heightened blood pressure reportedly demonstrate a reduced receptor population $(59,60)$. Changes occur in other organ systems as well $(44,61,62)$. Furthermore, the number of binding sites is modified by alterations in blood pressure. Data on binding affinity in these studies are conflicting. In other models of experimental hypertension, binding affinity is increased in the early hypertensive phase (63), while receptor density is unchanged or diminished in later periods $(45,47,48,64)$

Since hypertensive animals appear to have normal to elevated endogenous plasma ANP levels with decreased binding capacity, it is surprising that ANP infusions have an increased or prolonged effect on diuresis, natriuresis, and blood pressure in hypertensive rats and monkeys (65-69) as well as in humans with essential hypertension (70-72). We therefore evaluated the ANP response of guanylate cyclase in normotensive rats and SHR in studies aimed at elucidating its mechanism in this model of hypertension.

\section{Methods}

Materials. Male rats obtained from Taconic Farms Inc., Germantown, NY (WKY, SHR), Charles River, St-Constant, Que., Canada, and Harlan Sprague Dawley Inc., Indianapolis, IN, were kept at room temperature under a $12 \mathrm{~h}: 12 \mathrm{~h}$ dark/light cycle. They were fed normal Purina rat chow and allowed free access to tap water. Synthetic rat $\mathrm{ANP}^{99-126}$ and leupeptin were purchased from Institut Armand-Frappier, Laval, Que., Canada. C-ANP ${ }^{102-121}$-des [Gln ${ }^{116}, \operatorname{Ser}^{117}$, Gly ${ }^{118}$, Leu $^{119}$, Gly ${ }^{120}$ ]ANP-NH 2 (C-ANP) was generously donated by BioMega, Chomedey, Laval, Que., Canada. Carrier-free ${ }^{125} \mathrm{I}-\mathrm{Na}$ was acquired from Amersham Corp., Oakville, Ont., Canada; disuccinimidyl suberate (DSS) and Triton X-100 were procured from Pierce, Rockford, IL, USA. Electrophoresis reagents and molecular weight standards were obtained from Bio-Rad, Mississauga, Ont., Canada. Lactoperoxidase and bovine gamma-globulin came from Sigma, St. Louis, MO.

Tissue preparations. Male rats were decapitated between 8 to 10 a.m. to exclude a possible effect of diurnal variations. Their kidneys were rapidly removed and placed in gas-modified $\left(95 \% \mathrm{O}_{2} / 5 \% \mathrm{CO}_{2}\right)$ Krebs solution, $\mathrm{pH} 7.4$, at $4^{\circ} \mathrm{C}$. The cortex was separated, cut into slices, and gently ground successively through 250 - and $150-\mu \mathrm{m}$ molecular sieves. The pass-through fraction was washed three times with Krebs solution on a 70- $\mu \mathrm{m}$ mesh. The supernatant was then centrifuged three times at $400 \mathrm{~g}$ for $3 \mathrm{~min}$. The purity of the suspensions, verified by phase contrast microscopy, was over $95 \%$. Protein concentrations of glomerular preparations were measured by the method described by Lowry et al. (73).

Whole lungs and livers were also removed, while the renal papilla and zona glomerulosa were dissected from the kidney and adrenal cortex respectively. The tissues were homogenized with a Potter-Elvehjem homogenizer for large preparations or with a Dounce homogenizer for smaller samples in 5 vols of ice-cold $50 \mathrm{mM}$ Hepes buffer, $\mathrm{pH} 7.4$, containing $1 \mathrm{mM}$ EDTA, $10 \mu \mathrm{g} / \mathrm{ml}$ leupeptin, and $0.1 \mathrm{mM}$ PMSF. After centrifugation at $30,000 \mathrm{~g}$ for $30 \mathrm{~min}$, the pellets were resus- pended and centrifuged a second time. Washed pellets were resuspended in the same buffer at a protein concentration of $\sim 20 \mathrm{mg} / \mathrm{ml}$.

Stimulation of $c G M P$ production in glomeruli. Isolated glomeruli (6) in the amount of $400-500 \mu \mathrm{g}$ were incubated in $400 \mu \mathrm{l} \mathrm{Krebs} \mathrm{solu-}$ tion for $15 \mathrm{~min}$ at $37^{\circ} \mathrm{C}$ and for 2 additional min with $500 \mu \mathrm{M}$ of the phosphodiesterase inhibitor, methylisobutylxanthine (MIX; reference $9)$. Acetic acid $(0.01 \mathrm{~N})$ or increasing concentrations of ANP $\left(10^{-10}\right.$ to $10^{-6} \mathrm{M}$ ) were then added. The reaction was stopped after $90 \mathrm{~s}$ with $1 \mathrm{~N}$ perchloric acid. The samples were rapidly frozen in liquid nitrogen and kept at $-35^{\circ} \mathrm{C}$ until sonication, extraction, and cGMP measurement by RIA, as described previously $(74,75)$.

Solubilization of membranes. Glomeruli and papilla were isolated as described above. For binding and crosslinking studies, the membrane fractions were solubilized with $3 \%$ Triton X-100 for $60 \mathrm{~min}$ at $4^{\circ} \mathrm{C}$ in $50 \mathrm{mM}$ Hepes buffer, $\mathrm{pH} 7.4$, containing $1 \mathrm{mM}$ EDTA, 50 $\mu \mathrm{g} / \mathrm{ml}$ leupeptin, $0.1 \mathrm{mM}$ PMSF, and $0.6 \mathrm{M} \mathrm{KCl}$. The samples were then centrifuged at $105,000 \mathrm{~g}$ for $30 \mathrm{~min}$ and resuspended in the same buffer. Protein content was measured by Peterson's method (76).

Receptor binding assay. ANP ${ }^{99-126}$ was iodinated with $1 \mathrm{mCi}$ of ${ }^{125}$ I-labeled $\mathrm{Na}$ by the lactoperoxidase method and purified by HPLC on a $\mathrm{C}_{18} \mu$-Bondapak column, as described previously (77). For ANP binding assay, glomeruli were isolated and membranes solubilized as detailed above. Briefly, $50 \mu \mathrm{g}$ of protein were incubated with ${ }^{125} \mathrm{I}-\mathrm{la}$ beled ANP $(10,000 \mathrm{cpm})$ for $60 \mathrm{~min}$ at $22^{\circ} \mathrm{C}$ in $100 \mathrm{mM}$ phosphate buffer, $\mathrm{pH} 7.4,10 \mu \mathrm{g} / \mathrm{ml}$ aprotinin, $10 \mu \mathrm{g} / \mathrm{ml}$ leupeptin, $5 \mathrm{mM} \mathrm{MgCl}$, $0.5 \mathrm{mM}$ PMSF, $0.4 \% \mathrm{BSA}$ and $0.1 \%$ Triton X-100 in the absence or presence of increasing concentrations of cold ANP ${ }^{99-126}$ or CANP $^{102-121}$ in a final volume of $100 \mu$ l. Nonspecific binding was determined in the presence of $1 \mu \mathrm{M}$ of unlabeled ANP ${ }^{99-126}$. At the end of incubation, $25 \mu \mathrm{l}$ of bovine gamma-globulin $(0.3 \%)$ and $1 \mathrm{ml}$ of polyethyleneglycol (PEG; 16\%) in phosphate buffer, $\mathrm{pH} 7.4$, were added. The incubation mixture was immediately poured onto polyethylenimine-treated $(0.3 \%, 30 \mathrm{~min})$ Whatman GF/C fiberglass filters, rinsed three times with $1 \mathrm{ml}$ PEG, and its radioactivity was counted with a Gamma counter.

Affinity cross-linking with ${ }^{125} I-A N P$. Triton X-100-solubilized glomerular or papillar proteins $(500 \mu \mathrm{g})$ were incubated with $0.1 \mathrm{nM}$ ${ }^{125}$ I-labeled ANP $\left(5 \times 10^{6} \mathrm{cpm}\right)$ for $60 \mathrm{~min}$ at $22^{\circ} \mathrm{C}$ in $1 \mathrm{ml}$ of sodium phosphate buffer, pH 7.4, containing $0.1 \mathrm{mM} \mathrm{PMSF}, 10 \mu \mathrm{g} / \mathrm{ml}$ aprotinin, $10 \mu \mathrm{g} / \mathrm{ml}$ leupeptin, and $5 \mathrm{mM} \mathrm{MgCl}$ in the absence or presence of $0.1 \mu \mathrm{M}$ unlabeled C-ANP ${ }^{102-121}$ or ANP ${ }^{99-126}$. After incubation, the protein-bound radioactivity was isolated by gel filtration on Sephadex G-50 $(0.5 \times 14 \mathrm{~cm})$, and the cross-linking reagent DSS was added at a final concentration of $0.5 \mathrm{mM}$ and incubated for $15 \mathrm{~min}$ at $22^{\circ} \mathrm{C}$. The final reaction was quenched by $50 \mathrm{mM}$ ammonium acetate. Bound ${ }^{125}$ I-labeled ANP was detected by autoradiography after SDS-PAGE.

Guanylate cyclase assay. Particulate guanylate cyclase activity was measured in membranes of various tissues, as described previously (78). The reaction mixture $(0.1 \mathrm{ml})$ contained $9.25 \mathrm{mg} / \mathrm{ml}$ phosphocreatine, $2.5 \mathrm{mg} / \mathrm{ml}$ creatine phosphokinase, $2 \mathrm{mM}$ MIX, $10 \mathrm{mM}$ theophylline, $3 \mathrm{mM}$ excess $\mathrm{MnCl}_{2}, 1 \mathrm{mM} \mathrm{GTP}-\mathrm{MnCl}_{2}$, and $50 \mathrm{mM}$ triethanolamine buffer, $\mathrm{pH} 7.4$, in the absence or presence of $1 \mu \mathrm{M}$ ANP. Membrane proteins or solubilized preparations were added, incubated at $37^{\circ} \mathrm{C}$ for $30 \mathrm{~min}$, and the reaction was stopped with $2 \mathrm{ml}$ of $30 \mathrm{mM}$ hot EDTA. cGMP formed was measured by radioimmunoassay $(74,75)$.

Radiation-inactivation. Pulmonary membrane preparations were brought to $2 \mathrm{mg} / \mathrm{ml}$ of proteins and pre-incubated at $4^{\circ} \mathrm{C}$ for $10 \mathrm{~min}$ with $0.01 \mathrm{~N}$ acetic acid or with $0.5 \mu \mathrm{M}$ ANP, a dose which was shown in pilot experiments to fully activate guanylate cyclase. Control and ANPtreated samples were quickly aliquoted into Eppendorf tubes $(200 \mu \mathrm{l})$ and rapidly frozen in liquid nitrogen. Samples kept at $-78^{\circ} \mathrm{C}$ with dry ice at exposure times varying between 0 and $24 \mathrm{~h}$ were irradiated in a Gammacell 220 irradiator (Atomic Energy of Canada Ltd., Ottawa, Ont., Canada) delivering a steady dose of about $1.35 \mathrm{Mrads} / \mathrm{h}$ (7981 ). Residual guanylate cyclase activity assessed on rapidly-thawed samples was plotted semilogarithmically as a function of radiation dose. A line passing near $2(100 \%$ activity) at 0 radiation dose was 
constructed by least square analysis. The radiation-inactivation size ( or RIS) of the functional unit studied was calculated by the equation

$\log \mathrm{RIS}=5.89-\log \mathrm{D}_{37}-0.0028 t$

where $D_{37}$ is the radiation dose needed to decrease the function of a protein to $37 \%$ of its initial value (82) and $t$ is the temperature during radiation (83).

Quantitative measurement of ANP A- and B-receptor mRNA transcripts, with regard to (a) preparation of mutant $A N P A$ - and $B$-receptor $c D N A$ and $c R N A$. To clone a fragment of ANP A-receptor CDNA, total RNA from rat pituitaries was extracted and transcribed into cDNA with M-MLV reverse transcriptase (Bethesda Research Laboratories, Bethesda, MD) primed with random hexamers according to the manufacturer's protocol. A $709 \mathrm{bp}$ fragment was generated by 30 cycles of polymerase chain reaction (PCR) in a thermocycler (Perkin Elmer Cetus, Norwalk, CT) as described below. The sense and antisense primers were respectively: GGAGAGAACACAAGCTTATCTGGAGG and AAAGTCGACCCCGGGAGGTCAGCCTCGAGTGGCTACA. The sense primer from base 2712 (84) contained a HindIII site (underlined) while the antisense primer from base 3404 was extended in $5^{\prime}$ with two sites, Sal I and Sma I. Using these sites, the PCR fragment was cloned into the plasmid pSP72.

A mutant ANP A-receptor cDNA fragment was obtained by PCR with oligos containing mismatched bases $(\mathrm{G} \rightarrow \mathrm{T}$ at $3027, \mathrm{G} \rightarrow \mathrm{C}$ at 3028), creating an EcoRI site at position 3023 of ANP A-receptor cDNA. This mutated partial cDNA was cloned into pSP73. The mutant ANP B-receptor ( $795 \mathrm{bp}$ ) cDNA fragment, from bases 2425 to 3213 of the reported sequence (26) was obtained using the same strategy and the following oligos sense primer from 2489 GGTGGTACCAGCATATTGGAC containing a KpnI site (underlined) and antisense from 3193 AAAAGATCTTACAGGAGTCCAGGAGGTCCT extended with a Bgl II site. Two point mutations $(\mathrm{A} \rightarrow \mathrm{T}$ at 2837 and $G \rightarrow C$ at 2839 ) were introduced by PCR primed with mismatched oligos to create an EcoRI site at position 2835. The mutant ANP-B cDNA fragment was then inserted into pSP72. Mutant cRNA nolecules were then generated by in vitro transcription using the Riboprobe II core system (Promega, Madison, WI). These mutant RNAs were employed as internal standards in reverse transcription and quantitative PCR or as exogenous RNAs in modified PCR aided transcript titration assays. ${ }^{2}$ The cRNAs were stored in $1 \mu \mathrm{g} / 10 \mu \mathrm{l}$ aliquots at $-70^{\circ} \mathrm{C}$.

(b) Reverse transcription and quantitative PCR for ANP A- and $B$-receptors $m R N A$. Total cellular RNA was processed from rat lungs by the guanidinium isothiocyanate procedure ( 85$)$. Serial dilutions of mutant cRNA for the ANP A- or B-receptor were added to a fixed amount of tissue RNA, either before RNA extraction to determine the efficiency of extraction or before reverse transcription and PCR for the construction of titration curves. Fractions of 1 or $2 \mu \mathrm{g}$ total RNA were dissolved in water containing $100 \mathrm{pmol}$ random hexamers. After 10 min of denaturation at $70^{\circ} \mathrm{C}$, the solution was put on ice and mixed with $200 \mathrm{U}$ of superscript $\mathrm{RNase} \mathrm{H}^{-}$reverse transcriptase (Canadian Life Technologies, Burlington, Ont., Canada) in RT buffer (final concentration $50 \mathrm{mM}$ Tris $\mathrm{HCl}, \mathrm{pH} 8.3$, at $23^{\circ} \mathrm{C}$ ) containing $75 \mathrm{mM} \mathrm{KCl}$, $10 \mathrm{mM}$ DTT, $3 \mathrm{mM} \mathrm{MgCl}_{2}$, and $0.5 \mathrm{mM} \mathrm{dNTP} \mathrm{for} \mathrm{a} \mathrm{total} \mathrm{volume} \mathrm{of}$ $20 \mu \mathrm{l}$. After $1 \mathrm{~h}$ of incubation at $37^{\circ} \mathrm{C}$, one half of the reaction products was used for PCR amplification with the same set of primers described above for A or B receptor separately. A reaction volume of $50 \mu \mathrm{l}$ containing $50 \mathrm{mM}$ Tris- $\mathrm{HCl}$ buffer, $\mathrm{pH} 8.4,1.5 \mathrm{mM} \mathrm{MgCl}_{2}, 50 \mathrm{mM} \mathrm{KCl}$, $0.2 \mathrm{mM}$ dNTP, 50 pmol of each primer, $5 \mathrm{U}$ TAQ polymerase (Perkin Elmer Cetus), and $20 \mu \mathrm{Ci}{ }^{32} \mathrm{P}-\mathrm{dCTP}$ was incubated for 30 cycles of 1 min denaturation at $94^{\circ} \mathrm{C}, 1 \mathrm{~min}$ annealing at $65^{\circ} \mathrm{C}$, and $1 \mathrm{~min} 30 \mathrm{~s}$ of extension at $72^{\circ} \mathrm{C}$. After PCR, $10 \mu$ l of each sample were digested at

2. Fujio N., F. Bayard, F. Gossard, P. Hamet, and J. Tremblay. 1993. Differential messenger RNA expression of particulate guanylate cyclase A and B in rat tissues: Quantitative polymerase chain reaction analysis. (Manuscript submitted for publication.) $37^{\circ} \mathrm{C}$ for $1 \mathrm{~h}$ with $10 \mathrm{U}$ of EcoRI. The two sets of primers did not crossreact with the other subtype of ANP receptor CDNA (not shown). Digested and undigested samples were electrophoresed on $1.5 \%$ agarose gel and radioactive bands were quantified with a PhosphorImager (Molecular Dynamics, Sunnyvale, CA).

Statistics. The results are expressed as means \pm SEM. Comparisons were made by one- or two-way ANOVA with a posteriori comparisons according to Bonferroni's method, or by the unpaired Student's $t$ test. Differences were considered to be significant at $P<0.05$.

\section{Results}

Stimulation of cGMP production by ANP in glomeruli of normotensive and hypertensive rats. cGMP production was measured in glomeruli after 90 s incubation with $\mathrm{ANP}^{99-126}$ in three normotensive strains (WKY, Wistar, and Sprague-Dawley rats) and in SHR (Fig. 1). Previous experiments had shown that cGMP increased maximally after a 90 -s incubation period (6). Basal cGMP levels were similar in all four strains. ANP concentrations lower than $10^{-10} \mathrm{M}$ did not enhance cGMP generation over basal levels in glomeruli in any of these animals. At an ANP concentration of $10^{-9} \mathrm{M}$, cGMP levels in normotensive strains rose between 50 and $80 \%$ while there was a $120 \%$ elevation in hypertensive animals. At higher ANP concentrations, cGMP levels increased more than 33-fold in SHR, while in the normotensive strains, they did not exceed a 15-fold augmentation (Wistar 13 \pm 2 ; Wistar-Kyoto $12 \pm 2$; SpragueDawley $14 \pm 2$ ). ANOVA established that the difference between the normotensive and hypertensive strains was highly significant $(P<0.001)$ whereas cGMP elevations in glomeruli

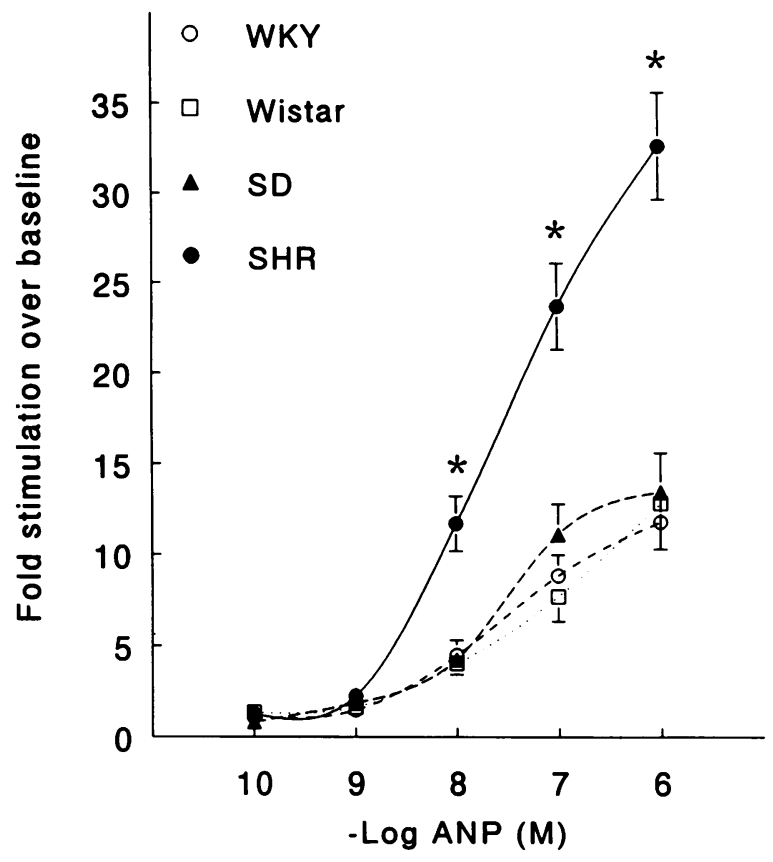

Figure 1. Effect of ANP on cGMP levels in glomeruli of SHR and different normotensive strains. Isolated glomeruli were incubated at $37^{\circ} \mathrm{C}$ with increasing concentrations of ANP in the presence of 0.5 mM MIX for 90 s. cGMP levels are expressed as means \pm SEM of fold increase ( $n=7$ animals of each strain). Baseline values of cGMP ( $\mathrm{pmol} / \mathrm{mg}$ protein) were similar in all strains: in WKY 1.74 \pm 0.21 ; in Wistar 1.83 \pm 0.19 ; in Sprague-Dawley 1.61 \pm 0.36 ; and in SHR $1.57 \pm 0.29$. ANOVA demonstrated a significant difference in SHR cGMP response vs. all other strains $(P<0.001)$. 
of the three normotensive strains did not differ significantly between each other.

Genetic heterogeneity has been demonstrated between animals from different commercial sources (86). We therefore evaluated the effect of a maximal dose of ANP $(1 \mu \mathrm{M})$ on cGMP levels in isolated glomeruli from SHR and WKY originating from three major commercial sources in North America. Our results showed that the phenotype of the glomerular cGMP response to ANP was well conserved and that a 2- to 3-fold difference was observed in the glomerular cGMP increase between WKY and SHR from the three commercial sources (Table I). The difference between WKY and SHR preceded the phase of established hypertension. Thus, the fold increase of glomerular cGMP levels by ANP was 8 and 33 for WKY and SHR, respectively, at 6 wk of age, 11 and 40 at 8 wk, 13 and 31 at $10 \mathrm{wk}$, and 15 and 30 in 14-wk-old rats. However, the difference appeared to be less striking at an older age, a finding that can be partly explained by an enhanced response (nearly doubling) in young vs. adult WKY animals. This difference between WKY and SHR persisted despite modulation of blood pressure. Indeed, prevention of the blood pressure increase in SHR by combined hydralazine $(10 \mathrm{mg} / \mathrm{kg}$ per d) and hydrochlorothiazide $(200 \mathrm{mg} / \mathrm{kg}$ per $\mathrm{d})$ therapy between the ages of 4 and 12 wk did not attenuate the exaggerated pattern of cGMP production, as compared to the stimulation observed in the normotensive control strain. In WKY, maximal stimulation was 16- and 20-fold over baseline in treated and untreated rats whereas in SHR, it was 46- and 41-fold over basal values under the same conditions (Fig. 2), despite 40 $\mathrm{mmHg}$ lower blood pressure $(132 \pm 2 \mathrm{mmHg}$ vs. $91 \pm 5 \mathrm{mmHg}$, respectively) in untreated and treated SHR.

Competitive ANP binding in glomeruli. The ANP binding characteristics of glomerular receptors in SHR, WKY, and Sprague-Dawley rats were determined by competitive binding of ${ }^{125}$ I-labeled ANP with increasing doses of rat ANP (Fig. 3). The dissociation constants of the various strains were not significantly different ( $\mathrm{Kd}$ in $10^{-10} \mathrm{M}$ : WKY 3.0 0.7 , SpragueDawley 4.6 \pm 1.8 , SHR 4.1 \pm 1.2$)$. Receptor density $\left(B_{\max }\right.$ in $\mathrm{fmol} / \mathrm{mg}$ protein ) was $520 \pm 120$ in WKY, 420 \pm 120 in SpragueDawley, and $810 \pm 230$ in SHR (difference not significant).

Comparison of $A N P^{99-126}$ and $C-A N P^{102-121}$ binding in glomeruli. C-ANP ${ }^{102-121}$ is a truncated ANP analog which is more specific for the C-receptor. It induces glomerular cGMP production only at micromolar concentrations, with a maximal $80 \%$ increase in cGMP levels as compared to more than 10 -fold for ANP ${ }^{99-126}$ in the same dose range (data not shown). Competitive inhibition of ${ }^{125} \mathrm{I}-\mathrm{ANP}$ binding by C-ANP ${ }^{102-121}$ and

Table I. Stimulation of cGMP Production by ANP (1 $\mu M)$ in Glomeruli Isolated from Rats Originating from Different Commercial Sources

\begin{tabular}{lccc}
\hline & \multicolumn{3}{c}{ Commercial source } \\
\cline { 2 - 4 } Strain & Charles River & Taconic & Harlan \\
\hline WKY & $10 \pm 4$ & $12 \pm 5$ & $14 \pm 6$ \\
SHR & 23 & $29 \pm 10^{*}$ & $40 \pm 1^{*}$
\end{tabular}

Glomeruli were isolated as described in Methods. Values represent the means \pm SEM of fold increase in cGMP levels over baseline. The number of experiments varied from 2 to $8 .{ }^{*} P<0.05$.

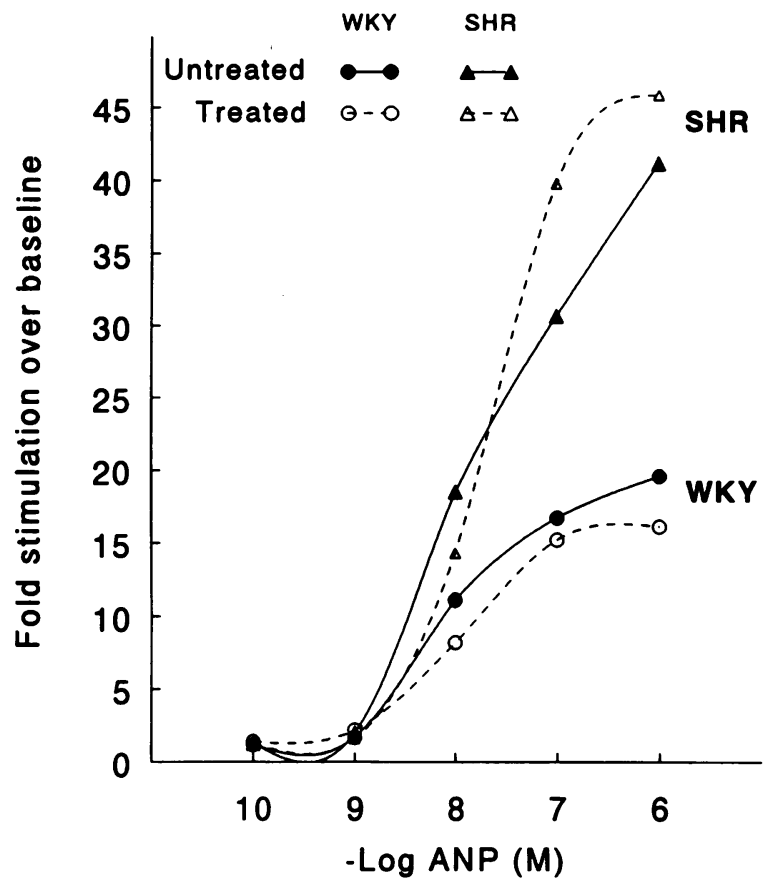

Figure 2. Effect of ANP on cGMP levels in WKY and SHR not treated or treated for $8 \mathrm{wk}$ with hydralazine and hydrochlorothiazide to normalize blood pressure. The results are expressed as fold increase over basal levels.

$\mathrm{ANP}^{99-126}$ can be used as an indicator of the proportion of guanylate cyclase-related (ANP A-plus B-) receptors. In glomeruli from WKY, C-ANP displaced a maximum of $84 \%$ of ${ }^{125} \mathrm{I}$-labeled ANP, indicating that the remaining $16 \%$ was not

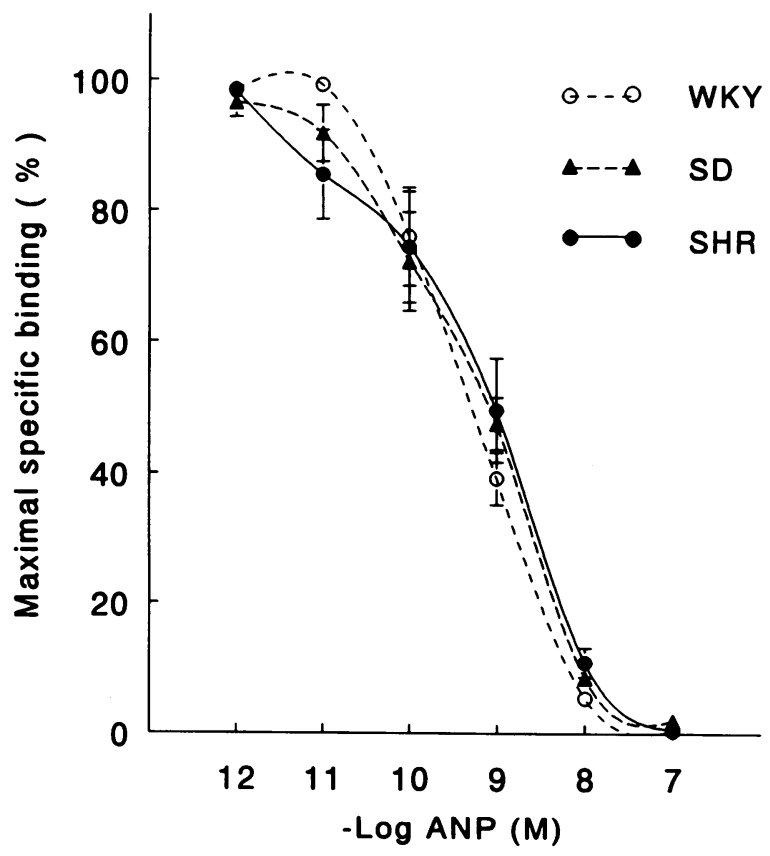

Figure 3. Competition for ${ }^{125}$ I-labeled ANP binding to isolated glomeruli from SHR, WKY, and Sprague-Dawley rats. Values are shown as means $\pm \operatorname{SEM}$ ( $n=7$ animals of each strain $)$ in \% of maximal specific binding. Nonspecific binding was obtained by incubation with 1 $\mu \mathrm{M}$ rat ANP. 
bound to the ANP C-receptor (Fig. 4). When the same type of experiment was performed in glomeruli from SHR, maximal displacement was $82 \%$ at $10^{-7} \mathrm{M}$ C-ANP, suggesting that $18 \%$ of the ANP receptors were not ANP C-receptors. These results indicate that in glomeruli, about $80 \%$ of ANP receptors are of the C-receptor type and that guanylate cyclase vs. C-receptor distribution is similar between WKY and SHR glomeruli.

Affinity cross-linking of ${ }^{125}$ I-labeled ANP in glomeruli and papillae from SHR and WKY rats. As described earlier (15, 18 ), affinity cross-linking in various tissues with ${ }^{125}$ I-labeled ANP specifically labels $65-$ and $130-\mathrm{kD}$ proteins. The high molecular weight form corresponds to the receptor containing particulate guanylate cyclase $(15,18)$. The $65-\mathrm{kD}$ protein is the ANP C-receptor that does not contain any intracellular catalytic activity. In glomeruli isolated from either WKY or SHR, both 130 - and $65-\mathrm{kD}$ proteins were labeled (Fig. $5 A$, lanes 1 and 4 ). Only the $65-\mathrm{kD}$ protein was competed for by C-ANP $\left(10^{-7} \mathrm{M}\right.$; Fig. $5 A$, lanes 2 and 5$)$ while ANP ${ }^{99-126}$ displaced both bands (Fig. $5 A$, lanes 3 and 6 ) in both strains. In both SHR and WKY papillae, affinity cross-linking with ${ }^{125}$ I-labeled ANP labeled only the $130-\mathrm{kD}$ protein (Fig. $5 \mathrm{~B}$, lanes 1 and 4 )

\section{A) Glomeruli from WKY}

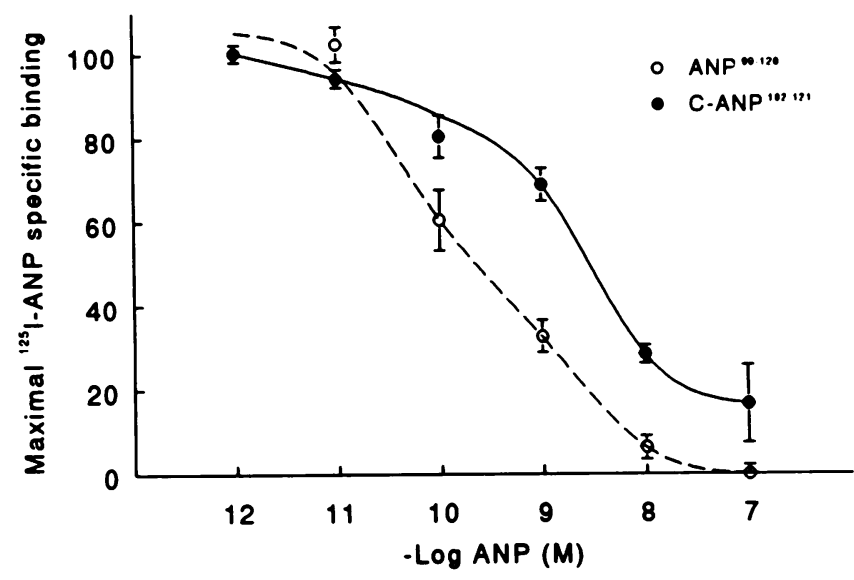

B) Glomeruli from SHR

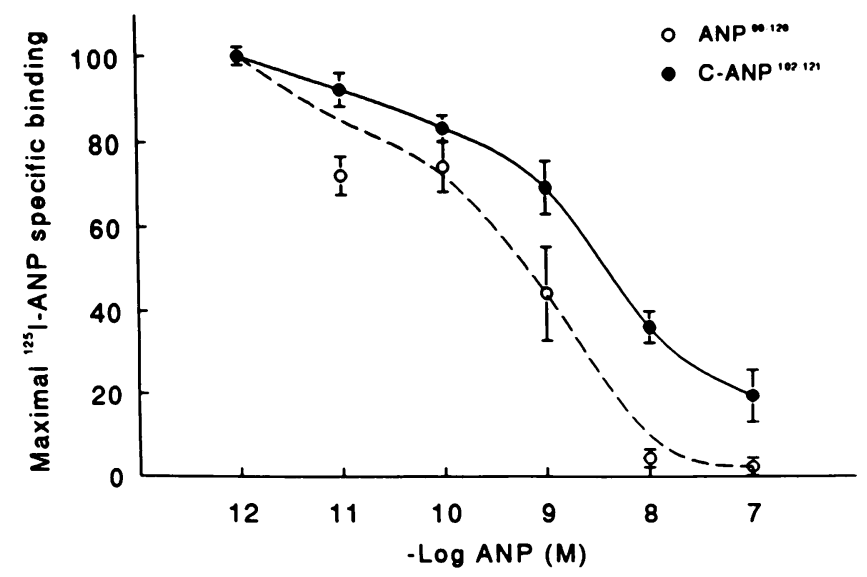

Figure 4. Competition of rat ANP ${ }^{99-126}$ and C-ANP ${ }^{102-121}$ for ${ }^{125}$ I-labeled ANP binding to isolated glomeruli from WKY and SHR. Values are expressed as means \pm SEM of maximal specific binding. Nonspecific binding was obtained by incubation with $1 \mu \mathrm{M}$ rat ANP.
A

GLOMERULI
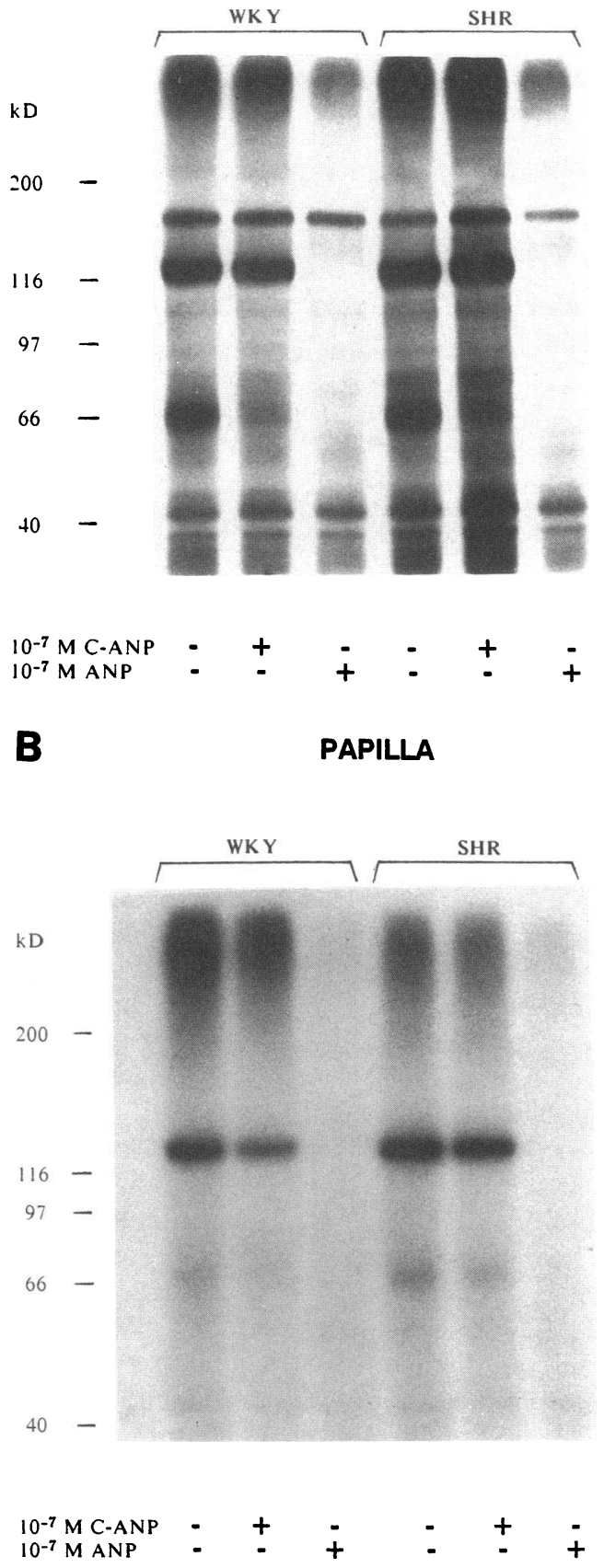

Figure 5. Affinity cross-linking with ${ }^{125}$ I-labeled ANP. Triton $\mathrm{X}$-100-solubilized glomerular $(A)$ or papillar membranes $(B)$ from WKY and SHR were incubated with ${ }^{125}$ I-labeled ANP in the absence (lanes 1 and 4 ) or presence (lanes 2 and 5 ) of $10^{-7} \mathrm{M}$ unlabeled C$\mathrm{ANP}^{102-121}$ or $10^{-7} \mathrm{M}$ unlabeled $\mathrm{ANP}^{99-126}$ (lanes 3 and 6), crosslinked with $0.5 \mathrm{mM}$ DSS, and subjected to PAGE and autoradiography.

which was also displaced by $\operatorname{ANP}^{99-126}\left(10^{6} \mathrm{M}\right.$; Fig. $5 \mathrm{~B}$, lanes 3 and 6 ) but not by the same dose of C-ANP (Fig. $5 \mathrm{~B}$, lanes 2 and 5 ). In Fig. $5 A$, the $175-\mathrm{kD}$ band was considered to be nonspecific, since it was neither displaced by ANP ${ }^{99-126}$ nor by C-ANP. Although some of the experiments (as shown in Fig. 5 $A$ and $B$ ) disclosed higher cross-linking of the radiolabeled li- 
Table II. Guanylate Cyclase Activity in Various Organs of Normotensive (WKY) and Spontaneously Hypertensive Rats (SHR)

\begin{tabular}{|c|c|c|c|c|c|c|}
\hline & \multicolumn{2}{|c|}{ Basal } & \multicolumn{2}{|c|}{ ANP } & \multicolumn{2}{|c|}{ Triton $\mathrm{X}-100$} \\
\hline & WKY & SHR & WKY & SHR & WKY & SHR \\
\hline Lung & $24 \pm 4$ & $64 \pm 6^{*}$ & $52 \pm 11$ & $116 \pm 12^{*}$ & $162 \pm 41$ & $288 \pm 41^{*}$ \\
\hline \multicolumn{7}{|l|}{ Kidney } \\
\hline -Glomeruli & $19 \pm 3$ & $51 \pm 22^{*}$ & $60 \pm 21$ & $110 \pm 64^{*}$ & $359 \pm 102$ & $617 \pm 180^{*}$ \\
\hline -Papilla & $35 \pm 7$ & $71 \pm 20^{*}$ & $104 \pm 15$ & $141 \pm 29$ & $408 \pm 219$ & $329 \pm 114$ \\
\hline Adrenal cortex & $48 \pm 10$ & $69 \pm 6^{*}$ & $106 \pm 18$ & $118 \pm 20$ & $475 \pm 87$ & $432 \pm 83$ \\
\hline Liver & $8 \pm 2$ & $8 \pm 1$ & $11 \pm 3$ & $10 \pm 1$ & $33 \pm 4$ & $38 \pm 1$ \\
\hline
\end{tabular}

Values expressed in pmol cGMP/min per mg prot. Data represent the means \pm SEM of determinations performed at three membrane protein concentrations from three different pooled samples ( 3 animals each, i.e., 9 animals of each strain). Membranes were incubated for 30 min in the absence (basal) or presence of either ANP $\left(10^{-6} \mathrm{M}\right)$ or Triton X-100 (3\% vol/vol) $\left({ }^{*} P<0.05\right.$ between two strains).

gand to the $130-\mathrm{kD}$ protein band in SHR, as compared to WKY, the difference did not reach statistical significance ( $n$ $=6$ ), pointing toward similar binding capacities in the two organs studied.

Guanylate cyclase activity. Guanylate cyclase activity was assessed directly in vitro in washed membranes prepared from various WKY and SHR organs ( Table II). Higher specific activity of particulate guanylate cyclase was found in membranes from the kidney papilla, adrenal cortex, and lungs, but not in the liver of SHR compared to WKY controls. When present, the greatest difference between WKY and SHR was observed for basal guanylate cyclase activity within its membrane environment. The difference between WKY and SHR decreased from basal to ANP-stimulated and Triton X-100-stimulated conditions, being least evident under the two latter conditions in the papilla and adrenal cortex. These results suggest that the basal specific activity of particulate guanylate cyclase within membranes of most organ systems is higher in SHR.

Radiation-inactivation. We attempted to characterize the behavior of the protein within its membrane environment in lung preparations from SHR and WKY by radiation-inactivation. This tissue source was chosen for its availability and similarity of guanylate cyclase behavior to glomerular tissues under basal, ANP-, and detergent-enhanced conditions (Table II). Under basal conditions, there is an activation hump in lung preparations from WKY and SHR rather than immediate destruction of enzymatic activity at doses up to 10 Mrads, followed by linear exponential decay. As reported previously (87, 88 ), this pattern is best explained by the presence of an intramolecular inhibitory component repressing guanylate cyclase activity in the basal state. ANP stimulation significantly enhanced guanylate cyclase decay by increasing doses of radiation in a monoexponential manner, most likely by liberating or deactivating the regulatory element (Fig. 6). Using the formula described in Methods, we calculated a RIS of $46 \mathrm{kD}$ in both basal and ANP-stimulated states. The values did not differ significantly between WKY and SHR. These results indicate that if the guanylate cyclase domain in the protein within its natural environment, or following stimulation by the ligand, is any different in SHR, it is below the determination capability of this method.

Quantitative assay of ANP receptor subtype $m R N A s$ by $P C R$-aided transcript titration. Total RNA from lung was used for the quantitation of ANP receptor mRNA. It can be seen from Table II that guanylate cyclase activity in the lung was well correlated with renal glomerular activity in both WKY and SHR under basal and ANP-induced conditions. Because the lung can be easily and rapidly dissected from the animal,
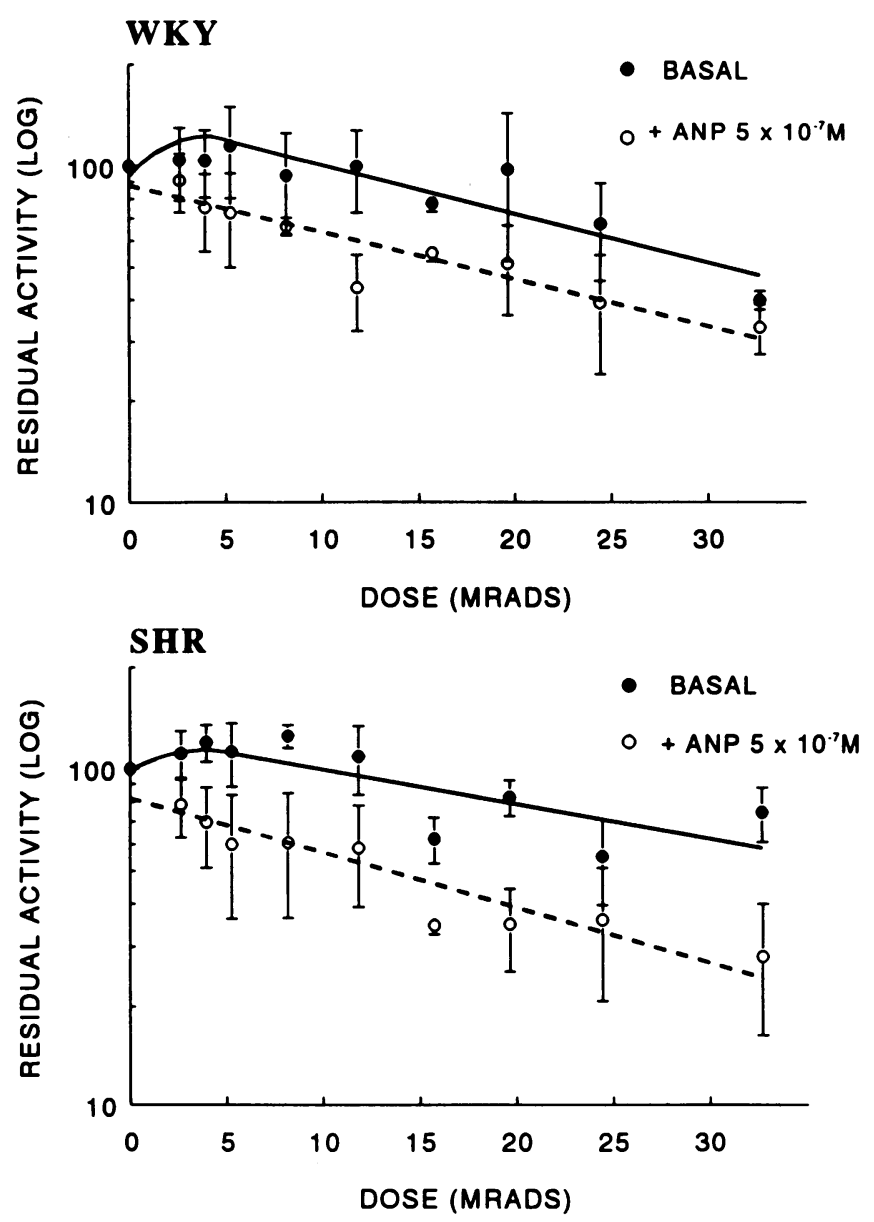

Figure 6. Radiation-inactivation of guanylate cyclase activity in lung membranes from WKY and SHR under basal conditions and ANP stimulation $(0.5 \mu \mathrm{M})$. Data points are means \pm SEM of four separate experiments, each performed in triplicate. They are plotted as $\log \%$ guanylate cyclase activity from baseline, representing nonirradiated samples $(\log 100 \%=2)$ as a function of increasing irradiation doses. Full symbols, controls; empty symbols, ANP-treated $\left(5 \times 10^{-7} \mathrm{M}\right)$. 
and because mRNA for both receptors are more abundant in this organ (26), it served as a source of RNA. Fig. $7 A$ shows a representative PhosphorImager picture of PCR products from total lung RNA of WKY and SHR rats titrated with $2 \times 10^{5}$, $10^{6}, 5 \times 10^{6}, 2 \times 10^{7}$ and $10^{8}$ molecules of mutated cRNAs of ANP-A and ANP-B receptors. After digestion with EcoRI, DNA fragments of 315 and 394 bp (lower bands) for ANP A-receptor and of 378 and 387 bp for ANP B-receptor were generated by mutant cDNAs. Titration curves were constructed for ANP A- and ANP B-receptor mRNAs, using a fixed amount of lung total RNA mixed with increasing amounts of mutated cRNA $\left(0.20\right.$ to $100 \times 10^{6}$ molecules $)$ before reverse transcription and PCR (Fig. 7 B). Percentages of ${ }^{32} \mathrm{P}$ radioactivity following EcoRI digestion in the upper band vs. the sum of the upper and lower bands were calculated; a $50 \%$ value corresponded to the absolute amount of ANP A- or B-receptor mRNA molecules per $\mu \mathrm{g}$ of total RNA. It was of relevance to analyze the ratio of $A$ and $B$ receptor mRNAs within each strain as well as the relative expression of $A$ and $B$ receptor mRNAs in WKY and SHR, respectively. Thus, the ANP B-receptor mRNA level was about threefold higher than that of ANP A-receptor in WKY rats, while in SHR both receptors were equally represented (Fig. $7 C$ ). Furthermore, additional measurements in six different tissue preparations showed that ANP A-receptor mRNA levels were significantly higher in SHR than in WKY $(P<0.01)$, while the amount of mRNA of the ANP B-receptor was not significantly different between the two strains. In addition to Charles River SHR, these experiments were performed on rat strains from Taconic Farms with the same results.

\section{Discussion}

We report here a highly significant increase of cGMP production (about threefold) in response to ANP in glomeruli from SHR when compared to three normotensive rat strains. This phenotype is constant between SHR and WKY strains from three different suppliers and is present early in the life of SHR. Since blood pressure normalization does not affect this phenomenon, it has to be examined for its primary involvement in hypertension. As a first step, the present studies aimed at determining the mechanism of this increased cGMP production.

Data on ANP binding affinities and receptor densities are conflicting. Several authors have reported normal or diminished receptor density in glomeruli from SHR or in experimental hypertension $(45,48,58-60)$. Our competitive binding studies did not show any significant difference in either total binding capacity or binding affinity between hypertensive and normotensive rats. This apparent contradiction may be due to the age of the animal studied and decrease in receptor density could be secondary to high blood pressure, since it is observed in experimental hypertension and older SHR. Furthermore, binding studies only demonstrate the presence of one binding site in spite of the existence of at least three different subtypes of ANP receptors $(24,26,30)$. In glomeruli, we performed competitive displacement of ${ }^{125}$ I-labeled ANP with C-ANP, an agonist specific for the C-receptor (31). C-ANP displaced 82 and $84 \%$ of specifically bound labeled ANP in WKY and SHR, respectively. This suggests that the remaining $16 \%$ and $18 \%$ of ${ }^{123}$ I-labeled ANP not bound to the C-receptor were bound to ANP A- and B-receptors and that the proportion of guanylate

\section{A-RECEPTOR}

A)

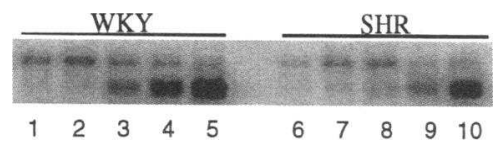

B)

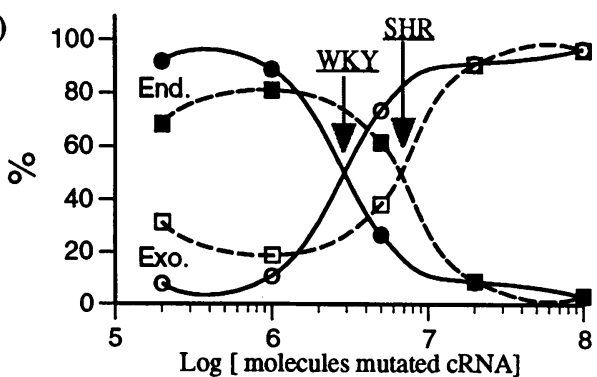

C)

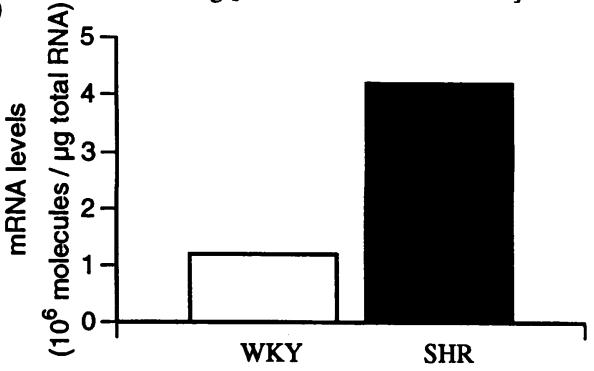

\section{B-RECEPTOR}
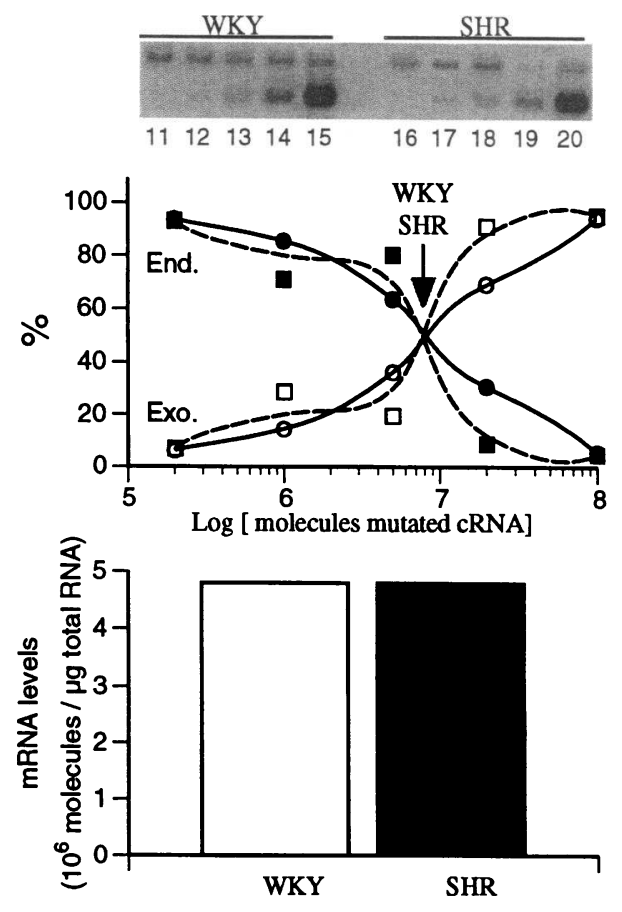

Figure 7. (A) Typical PCR transcript titration assay of ANP A- and ANP B-receptor mRNA in lung tissues. Total RNA from WKY (lanes 1 to 5 ) and SHR (lanes 6 to 10 ) were titrated with an increasing number $\left(2 \times 10^{5}, 10^{6}, 5 \times 10^{6}, 2\right.$ $\times 10^{7}, 10^{8}$ ) of molecules of mutated ANP A-receptor cRNA. Lanes 11 to 15 (WKY) and 16 to 20 (SHR) represent PCR transcript titration assay of ANP B-receptor mRNA with mutated ANP B-receptor cRNA as internal standard. $(B)$ Typical titration curves of ANP Aand B-receptor mRNA in lungs from WKY and SHR. $2 \mu \mathrm{g}$ of lung total RNA were titrated with increasing concentrations of mutated ANP A- or ANP B-receptor cRNA. Data points are plotted as \% radioactivity in the upper (End.) or lower $(E x o)$ bands after EcoRI digestion vs. molecules of cRNA. The ANP A-receptor $50 \%$ titration point was $2.4 \times 10^{6}$ molecules for WKY and $8.4 \times 10^{6}$ molecules $/ 2 \mu \mathrm{g}$ total RNA for SHR. The $50 \%$ titration point of ANP B-receptor mRNA was 9.6 $\times 10^{6}$ molecules $/ 2 \mu \mathrm{g}$ total RNA for both WKY and SHR rats. $(C)$ Histogram of ANP A- and ANP B-receptor mRNA levels per $\mu \mathrm{g}$ total RNA of lung tissues from WKY and SHR. 
cyclase (A- and B-receptors) to C-receptors was not different between the SHR and WKY strains.

Using affinity cross-linking with ${ }^{125} \mathrm{I}$-ANP in glomerular membranes, the density of radioactivity incorporated into 130and $65-\mathrm{kD}$ proteins was not clearly different between the two strains or between the ratio of $130-65-\mathrm{kD}$ (C-receptor) proteins. In papillae also, where only the guanylate cyclase-related receptor (130-kD protein) was detectable, binding capacity in SHR was only slightly higher. These results indicate that the higher cGMP increase in response to ANP was not due to gross overexpression of total particulate guanylate cyclase (ANP Aand B-receptors) at the cell surface. We report in the present study a threefold higher ANP B-receptor mRNA level compared to ANP A-receptor mRNA in the rat lung. This presumably translates into a difference in cell surface receptor proteins. With this cross-linking method, a slight increase in the ANP A-receptor may stay undetected. The elevated cGMP levels observed in intact glomeruli from SHR could be due to the synthesizing enzyme itself (guanylate cyclase), to a decrease in cGMP metabolism by phosphodiesterase, or to a defect in its egression (75). We thus directly assessed the activity of guanylate cyclase in vitro in washed glomerular membranes and in various organs under control conditions, after ANP and Triton $\mathrm{X}-100$ treatment, while inhibiting phosphodiesterase activity by MIX. A major, up to threefold difference was noted in the specific activity of the enzyme in glomerular membranes under basal conditions. The difference between the two strains decreased after ANP stimulation as well as under detergent-enhanced conditions. Thus, the enzyme's activity was higher in its natural membrane environment in SHR, and this characteristic was not compounded by greater sensitivity to ANP. These results suggest that either SHR guanylate cyclase was hyperactive in its basal state or that one guanylate cyclase population was increased but could not be detected by enhanced binding, indicating that ANP A-receptors expressed at a low level could be the target. In addition, the enzyme appeared to manifest a topographically different behavior. For example, in the renal papilla and zona glomerulosa, the difference in enzymatic activity observed under basal conditions was not found in the presence of the ligand or detergent. Conversely, the hyperactive state seen in SHR organs was not evident in the liver, pointing to the activation of one subtype of guanylate cyclase/ANP receptor.

Radiation-inactivation allows the in situ evaluation of molecular mass corresponding to a particular biological function. Only a few methods permit the study of protein size and interactions within their membranes without the necessity of prior solubilization or purification. Radiation-inactivation is one such technique. According to the target theory, in the simplest situations where only one component is responsible for the biological activity being assessed, radiation exposure leads to biological decay as a single exponential function of the absorbed dose (indicating destruction of crucial structures). The larger the structure, the more likely it will be hit. The only activity remaining after radiation exposure is due to units which have escaped ionization. They are fully active since there are no partially damaged targets. Our previous studies of the bovine adrenal cortex demonstrated that the ANP A-receptor is a multidomain protein. One domain of $20 \mathrm{kD}$ represents the binding site of the ligand, whereas another domain of $\sim 30 \mathrm{kD}$ bears the guanylate cyclase function, the two being separated by an inhibitory domain of $90 \mathrm{kD}(88)$. Our results indicate that the protein expressed in SHR underwent no major structural change in the overall guanylate cyclase domain and in the region more specifically activated by the ligand. Moreover, the pattern of enzymatic decay after exposure to radiation was similar in normotensive and hypertensive animals, and no gross abnormality was uncovered in the size of the regulatory element controlling enzymatic activity. Subtle intramolecular anomalies having no impact on molecular mass or regulation of biological function would not be depicted by this method.

Quantitative PCR has been employed recently to accurately determine the absolute amount of low abundance, specific mRNA $(89,90)$. We constructed mutated ANP A- and B-receptor cDNAs for use as internal standards for the quantification of low levels of mRNA. Since many variables involved in reverse transcription and PCR can affect the yield of quantitative PCR, the use of identical standards varying in only two bases in the middle of the sequence is of great advantage. In this study, we found a significantly higher expression of ANP A-receptor mRNA in lungs from SHR compared to WKY rats (close to threefold). Expression of the B-receptor mRNA was similar between WKY and SHR. Further studies aimed at the determination whether differences in gene expression of ANPA receptor are reflected at the protein level are currently being pursued in our laboratory.

In summary, in SHR, overexpression of the ANP A-receptor subtype could explain the overproduction of cGMP at basal levels. The abundance of the B-receptor over the A-receptor masked this overexpression in binding, cross-linking assays, and in total activation of guanylate cyclase by Triton X-100. Only precise mRNA quantitation of ANP receptor subtypes allowed the location of the difference between SHR and WKY.

It follows from our results that the abnormality in SHR should be observed only in tissues where the ANP A-receptor is expressed. In itself, this finding does not imply a primary pathogenetic role for this phenotype in the development of hypertension, but provides a tool to test this role in gene transfection and transgenic studies currently under way.

\section{Acknowledgments}

The authors thank Dr. Michel Potier for access to the Gammacell 220 Irradiator, Dr. Ernesto L. Schiffrin for use of the EBDA and LIGAND computer programs, Régis Tremblay, Bruno Lachance, and Suzanne Cossette for their excellent technical assistance, Louise Chevrefils for her secretarial skills, and Ovid Da Silva for editing this manuscript.

This work was supported by the Medical Research Council of Canada (grant MA-1 1463), and the Canadian Heart Foundation (grant to J. Tremblay). J. Tremblay is the recipient of a scholarship from Fonds de la Recherche en Santé du Québec. C. Huot and R. C. Willenbrock were fellows (Wi814/1-1) from the Deutsche Forschungsgemeinschaft and Fonds de la Recherche en Santé du Québec, respectively. F. Bayard was a visiting professor under the auspices of the Laboratory of Experimental Endocrinology, Centre Hospitalier Universitaire Rangueil, Toulouse, France.

\section{References}

1. De Bold, A. J. 1985. Atrial natriuretic factor: a hormone produced by the heart. Science (Wash. DC). 230:767-770.

2. Atlas, S. A., and J. H. Laragh. 1986. Atrial natriuretic peptide: a new factor in hormonal control of blood pressure and electrolyte homeostasis. Annu. Rev. Med. 37:397-414. 
3. Needleman, P., and J. E. Greenwald. 1986. Atriopeptin: a cardiac hormone intimately involved in fluid, electrolyte, and blood-pressure homeostasis. $N$. Engl. J. Med. 314:828-834.

4. Genest, J., and M. Cantin. 1987. Atrial natriuretic factor. Circulation 75(Suppl. I):I118-I124.

5. Huot, C., J. Tremblay, and P. Hamet. 1991. Cell biology of atrial natriuretic peptide. Blood Vessels. 28:84-92.

6. Tremblay, J., R. Gerzer, P. Vinay, S. C. Pang, R. Beliveau, and P. Hamet. 1985. The increase of CGMP by atrial natriuretic factor correlates with the distribution of particulate guanylate cyclase. FEBS (Fed. Eur. Biochem. Soc.) Lett. 181:17-22.

7. Ardaillou, N., M. P. Nivez, and R. Ardaillou. 1985. Stimulation of guanylate cyclase by atrial natriuretic factor in isolated human glomeruli. FEBS (Fed. Eur. Biochem. Soc.) Lett. 189:8-12.

8. Takeda, S., E. Kusano, N. Murayama, Y. Asano, S. Hosoda, H. Sokabe, and H. Kawashima. 1986. Atrial natriuretic peptide elevates cGMP contents in glomeruli and in distal tubules of rat kidney. Biochem. Biophys. Res. Commun. 136:947-954.

9. Ballermann, B. J., R. L. Hoover, M. J. Karnovsky, and B. M. Brenner. 1985. Physiologic regulation of atrial natriuretic peptide receptors in rat renal glomeruli. J. Clin. Invest. 76:2049-2056.

10. Napier, M. A., R. L. Vandlen, G. Albers-Schonberg, R. F. Nutt, S. Brady, T. Lyle, R. Winquist, E. P. Faison, L. A. Heinel, and E. H. Blaine. 1984. Specific membrane receptors for atrial natriuretic factor in renal and vascular tissues. Proc. Natl. Acad. Sci. USA. 81:5946-5950.

11. De Lean, A., P. Vinay, and M. Cantin. 1985. Distribution of atrial natriuretic factor receptors in dog kidney fractions. FEBS (Fed. Eur. Biochem. Soc.) Lett. 193:239-242.

12. Lynch, D. R., K. M. Brass, and S. H. Snyder. 1986. Atrial natriuretic factor receptors in rat kidney, adrenal gland, and brain: autoradiographic localization and fluid balance dependent changes. Proc. Natl. Acad. Sci. USA. 83:33573361 .

13. Healy, D. P., and D. D. Fanestil. 1986. Localization of atrial natriuretic peptide binding sites within the rat kidney. Am. J. Physiol. 250:F573-F578.

14. Bianchi, C., J. Gutkowska, G. Thibault, R. Garcia, J. Genest, and M. Cantin. 1986. Light and electron microscopic radioautographic localization of ${ }^{125}$ I-atrial natriuretic factor binding sites in the rat kidney. Proc. 1986 Annu. Meeting Endocrine Soc. 68:165.

15. Leitman, D. C., J. W. Andresen, T. Kuno, Y. Kamisaki, J. K. Chang, and F. Murad. 1986. Identification of multiple binding sites for atrial natriuretic factor by affinity cross-linking in cultured endothelial cells. J. Biol. Chem. 261:11650-11655.

16. Scarborough, R. M., D. B. Schenk, G. A. McEnroe, A. Arfsten, L. L. Kang, K. Schwartz, and J. A. Lewicki. 1986. Truncated atrial natriuretic peptide analogs. J. Biol. Chem. 261:12960-12964.

17. Pandey, K. N., S. N. Pavlou, and T. Inagami. 1988. Identification and characterization of three distinct atrial natriuretic factor receptors. J. Biol. Chem. 263:13406-13413.

18. Kuno, T., J. W. Andresen, Y. Kamisaki, S. A. Waldman, L. Y. Chang, S Saheki, D. C. Leitman, M. Nakane, and F. Murad. 1986. Co-purification of an atrial natriuretic factor receptor and particulate guanylate cyclase from rat lung. J. Biol. Chem. 261:5817-5823.

19. Paul, A. K., R. B. Marala, R. K. Jaiswal, and R. K. Sharma. 1987. Coexistence of guanylate cyclase and atrial natriuretic factor receptor in a $180-\mathrm{kD}$ protein. Science (Wash. DC). 235:1224-1226.

20. Takayanagi, R., R. M. Snajdar, T. Imada, M. Tamura, K. N. Pandey, K. S. Misono, and T. Inagami. 1987. Purification and characterization of two types of atrial natriuretic factor receptors from bovine adrenal cortex: guanylate cyclase-linked and cyclase-free receptors. Biochem. Biophys. Res. Commun. 144:244-250.

21. Meloche, S., N. McNicoll, B. Liu, H. Ong, and A. De Lean. 1988. Atrial natriuretic factor $\mathbf{R}^{1}$ receptor from bovine adrenal zona glomerulosa: purification, characterization, and modulation by amiloride. Biochemistry. 27:81518158 .

22. Singh, S., D. G. Lowe, D. S. Thorpe, H. Rodriguez, W. J. Kuang, L. J. Dangott, M. Chinkers, D. V. Goeddel, and D. L. Garbers. 1988. Membrane guanylate cyclase is a cell-surface receptor with homology to protein kinases. Nature (Lond.). 334:708-712.

23. Thorpe, D. S., and D. L. Garbers. 1989. The membrane form of guanylate cyclase-Homology with a subunit of the cytoplasmic form of the enzyme. $J$. Biol. Chem. 264:6545-6549.

24. Chang, M. S., D. G. Lowe, M. Lewis, R. Hellmiss, E. Chen, and D. V. Goedel. 1989. Differential activation by atrial and brain natriuretic peptides of two different receptor guanylate cyclases. Nature (Lond.). 341:68-72.

25. Lowe, D. G., M. S. Chang, R. Hellmiss, E. Chen, S. Singh, D. L. Garbers, and D. V. Goeddel. 1989. Human atrial natriuretic peptide receptor defines a new paradigm for second messenger signal transduction. EMBO (Eur. Mol. Biol. Organ.) J. 8:1377-1384.
26. Schulz, S., S. Singh, R. A. Bellet, G. Singh, D. J. Tubb, H. Chin, and D. L. Garbers. 1989. The primary structure of a plasma membrane guanylate cyclase demonstrates diversity within this new receptor family. Cell. 58:1155-1162.

27. Koller, K. J., D. G. Lowe, G. L. Bennett, N. Minamino, K. Kangawa, H. Matsuo, and D. V. Goeddel. 1991. Selective activation of the B natriuretic peptide receptor by C-type natriuretic peptide (CNP). Science (Wash. DC). 252:120-123.

28. Yamaguchi, M., L. J. Rutledge, and D. L. Garbers. 1990. The primary structure of the rat guanylate cyclase $\mathrm{A} /$ atrial natriuretic peptide receptor gene. $J$. Biol. Chem. 265:20414-20420.

29. Chinkers, M., and D. L. Garbers. 1989. The protein kinase domain of the ANP receptor is required for signaling. Science (Wash. DC). 245:1392-1394.

30. Fuller, F., J. G. Porter, B. E. Arfsten, J. Miller, J. W. Schilling, R. M. Scarborough, J. A. Lewicki, and D. B. Schenk. 1988. Atrial natriuretic peptide clearance receptor. J. Biol. Chem. 269:9395-9401.

31. Maack, T., M. Suzuki, F. A. Almeida, D. Nussenzveig, R. M. Scarborough, G. A. McEnroe, and J. A. Lewicki. 1987. Physiological role of silent receptors of atrial natriuretic factor. Science (Wash. DC). 238:675-678.

32. Nussenzveig, D. R., J. A. Lewicki, and T. Maack. 1990. Cellular mechanisms of the clearance function of type $\mathrm{C}$ receptors of atrial natriuretic factor. $J$. Biol. Chem. 265:20952-20958.

33. Cahill, P. A., E. M. Redmond, and A. K. Keenan. 1990. Vascular atrial natriuretic factor receptor subtypes are not independently regulated by atrial peptides. J. Biol. Chem. 265:21896-21906.

34. Sugawara, A., K. Nakao, M. Sakamoto, N. Morii, T. Yamada, H. Itoh, S. Shiono, and H. Imura. 1985. Plasma concentration of atrial natriuretic polypeptide in essential hypertension. Lancet II:1426-1427.

35. Sagnella, G. A., N. D. Markandu, A. C. Shore, and G. A. MacGregor. 1986. Raised circulating levels of atrial natriuretic peptides in essential hypertension. Lancet I:179-181

36. Sagnella, G. A., N. D. Markandu, M. G. Buckley, A. C. Shore, A. L. Sugden, D. R. J. Singer, and G. A. MacGregor. 1988. Plasma atrial natriuretic peptide in essential hypertension. Am. J. Hypertens. 1:112-118.

37. Sakamoto, M., I. Tanaka, Y. Oki, Y. Ikeda, M. Nanno, and T. Yoshimi. 1987. Atrial natriuretic peptide and vasopressin in human plasma. Peptides 9:187-191.

38. Arendt, R. M., E. Stangl, J. Zahringer, D. C. Liebisch, and A. Herz. 1985. Demonstration and characterization of $\alpha$-human atrial natriuretic factor in human plasma. FEBS (Fed. Eur. Biochem. Soc.) Lett. 189:57-60.

39. Wambach, G., G. Bonner, M. Stimpel, and W. Kaufmann. 1988. Relationship between plasma atrial natriuretic peptide and left atrial and left ventricular involvement in essential hypertension. J. Hypertens. 6:573-577.

40. Imada, T., R. Takayanagi, and T. Inagami. 1985. Changes in the content of ANF with the progression of hypertension in SHR. Biochem. Biophys. Res. Commun. 133:759-765.

41. Morii, N., K. Nakao, M. Kihara, A. Sugawara, M. Sakamoto, Y. Yamori, and H. Imura. 1986. Decreased content in left atrium and increased plasma concentration of atrial natriuretic polypeptide in spontaneously hypertensive rats (SHR) and SHR stroke-prone (SHRSP). Biochem. Biophys. Res. Commun. 135:74-81.

42. Gutkowska, J., K. Horky, C. Lachance, K. Racz, R. Garcia, G. Thibault, O. Kuchel, J. Genest, and M. Cantin. 1986. Atrial natriuretic factor in spontaneously hypertensive rats. Hypertension. 8(Suppl. I):I137-I140.

43. Khalil, F., B. Fine, S. Kuriyama, N. Hatori, A. Nakamura, M. Nakamura, and A. Aviv. 1987. Increased atrial natriuretic factor receptor density in cultured vascular smooth muscle cells of the spontaneously hypertensive rat. Clin. Exp. Hypertens. (A). 9:741-752.

44. Takayanagi, R., T. Imada, R. T. Grammer, K. S. Misono, M. Naruse, and T. Inagami. 1986. Atrial natriuretic factor in spontaneously hypertensive rats: concentration changes with the progression of hypertension and elevated formation of cyclic GMP. J. Hypertens. 4(Suppl. 3):S303-S307.

45. Garcia, R., G. Gauquelin, M. Cantin, and E. L. Schiffrin. 1988. Renal glomerular atrial natriuretic factor receptors in one-kidney, one clip rats. Hypertension. 11:185-190.

46. Garcia, R., M. Cantin, J. Gutkowska, and G. Thibault. 1987. Atrial natriuretic factor during development and reversal of one-kidney, one clip hypertension. Hypertension. 9:144-149.

47. Gauquelin, G., E. L. Schiffrin, M. Cantin, and R. Garcia. 1987. Specific binding of atrial natriuretic factor to renal glomeruli in doca-salt-treated rats: correlation with atrial and plasma levels. Biochem. Biophys. Res. Commun. 145:522-531.

48. Gauquelin, G., E. L. Schiffrin, M. Cantin, and R. Garcia. 1988. Atrial natriuretic factor: specific binding to renal glomeruli during the development of two-kidney, one-clip hypertension in the rat. J. Hypertens. 6:587-592.

49. Larochelle, P., J. R. Cusson, J. Gutkowska, E. L. Schiffrin, P. Hamet, O. Kuchel, J. Genest, and M. Cantin. 1987. Plasma atrial natriuretic factor concentrations in essential and renovascular hypertension. Br. Med. J. 294:1249-1252.

50. Yamaji, T., M. Ishibashi, H. Sekihara, F. Takaku, H. Nakaoka, and J. 
Fujii. 1986. Plasma levels of atrial natriuretic peptide in primary aldosteronism and essential hypertension. J. Clin. Endocrinol. Metab. 63:815-818.

51. Zachariah, P. K., J. C. Burnett, Jr., S. Ritter, and C. G. Strong. 1986. Atrial natriuretic peptide in essential hypertension. Clin. Res. 34:489A.

52. Haass, M., N. Zamir, and Z. Zukowska-Grojec. 1986. Plasma levels of atrial natriuretic peptides in conscious adult spontaneously hypertensive rats. Clin. Exp. Hypertens. (A). 8:277-287.

53. Hirata, Y., S. Hirose, S. Takata, Y. Takagi, and H. Matsubara. 1987. Down-regulation of atrial natriuretic peptide receptor and cyclic GMP response in cultured rat vascular smooth muscle cells. Eur. J. Pharmacol. 135:439-442.

54. Neuser, D., and P. Bellemann. 1986. Receptor binding, cGMP stimulation and receptor desensitization by atrial natriuretic peptides in cultured A10 vascular smooth muscle cells. FEBS (Fed. Eur. Biochem. Soc.) Lett. 209:347351.

55. Roubert, P., M. O. Lonchampt, P. E. Chabrier, P. Plas, J. Goulin, and P Braquet. 1987. Down-regulation of atrial natriuretic factor receptors and correlation with cGMP stimulation in rat cultured vascular smooth muscle cells. Biochem. Biophys. Res. Commun. 148:61-67.

56. Hughes, R. J., R. S. Struthers, A. M. Fong, and P. A. Insel. 1987. Regulation of the atrial natriuretic peptide receptor on a smooth muscle cell. Am. $J$ Physiol. 253:C809-C816.

57. Schiffrin, E. L., J. St-Louis, P. Hamet, and R. Garcia. 1990. Vascular receptors for atrial natriuretic peptide in spontaneously hypertensive rats. In Progress in Atrial Peptide Research (American Society of Hypertension Symposium Series), Vol. 3. B. M. Brenner and J. H. Laragh, editors. Raven Press, New York. 564-566.

58. Kurihara, M., J. S. Gutkind, and J. M. Saavedra. 1988. Alteration of atrial natriuretic peptide binding sites in spontaneously hypertensive rats. $\mathrm{Am}$. J. Hy pertens. 1(Suppl.):12S-14S.

59. Saito, H., K. I. Inui, Y. Matsukawa, T. Okano, H. Maegawa, K. Nakao, N. Morii, H. Imura, S. Makino, and R. Hori. 1986. Specific binding of atrial natriuretic polypeptide to renal basolateral membranes in spontaneously hypertensive rats (SHR) and stroke-prone SHR. Biochem. Biophys. Res. Commun. 137:10791085.

60. Swithers, S. E., R. E. Stewart, and R. McCarty. 1987. Binding sites for atrial natriuretic factor (ANF) in kidneys and adrenal glands of spontaneously hypertensive (SHR) rats. Life Sci. 40:1673-1681.

61. Schiffrin, E. L., J. St-Louis, R. Garcia, G. Thibault, M. Cantin, and J. Genest. 1986. Vascular and adrenal binding sites for atrial natriuretic factor: effects of sodium and hypertension. Hypertension. 8(Suppl. I):I141-I145.

62. Kurihara, M., S. Katamine, and J. M. Saavedra. 1987. Atrial natriuretic peptide, ANP (99-126), receptors in rat thymocytes and spleen cells. Biochem. Biophys. Res. Commun. 145:789-796.

63. Stewart, R. E., S. E. Swithers, and R. McCarty. 1987. Alterations in binding sites for atrial natriuretic factor in kidneys and adrenal glands of Dahl hypertension-sensitive rats. J. Hypertens. 5:481-487.

64. Gauquelin, G., R. Garcia, F. Carrier, M. Cantin, J. Gutkowska, G. Thibault, and E. L. Schiffrin. 1988. Glomerular ANF receptor regulation during changes in sodium and water metabolism. Am. J. Physiol. 254:F51-F55.

65. Pang, S. C., M. C. Hoang, J. Tremblay, M. Cantin, R. Garcia, J. Genest, and P. Hamet. 1985. Effect of natural and synthetic atrial natriuretic factor on arterial blood pressure, natriuresis and cyclic GMP excretion in spontaneously hypertensive rats. Clin. Sci. 69:721-726.

66. Garcia, R., G. Thibault, J. Gutkowska, K. Horky, P. Hamet, M. Cantin, and J. Genest. 1985. Chronic infusion of low doses of atrial natriuretic factor (ANF Arg 101-Tyr 126) reduces blood pressure in conscious SHR without apparent changes in sodium excretion. Proc. Soc. Exp. Biol. Med. 179:396-401.

67. Garcia, R., G. Thibault, P. Hamet, J. Gutkowska, M. Cantin, and J. Genest. 1985. Effect of atrial natriuretic factor [ANF (Arg 101-Tyr 126)] on kallikrein and cyclic GMP in the renovascular hypertensive rat. Clin. Exp. Hypertens. (A). 7:1597-1618.

68. Kondo, K., O. Kida, K. Kangawa, H. Matsuo, and K. Tanaka. 1985 Enhanced diuretic response to alpha-human atrial natriuretic polypeptide (alpha-hANP) in spontaneously hypertensive rats. Nippon Jinzo Gakkai Shi. 27:1313-1315.
69. Hamet, P., E. Testaert, R. Palmour, P. Larochelle, M. Cantin, S. Martin, F. Ervin, and J. Tremblay. 1989. Effect of prolonged infusion of ANF in normotensive and hypertensive monkeys. Am. J. Hypertens. 2:690-695.

70. Weidmann, P., M. P. Gnadinger, H. R. Ziswiler, S. Shaw, C. Bachmann, W. Rascher, D. E. Uehlinger, L. Hasler, and F. C. Reubi. 1986. Cardiovascular, endocrine and renal effects of atrial natriuretic peptide in essential hypertension. J. Hypertens. 4(Suppl. 2):S71-S83.

71. Cusson, J. R., G. Thibault, O. Kuchel, P. Hamet, M. Cantin, and P. Larochelle. 1989. Cardiovascular, renal and endocrine responses to low doses of atrial natriuretic factor in mild essential hypertension. J. Human. Hypertens. 3:89-96.

72. Janssen, W. M. T., D. De Zeeuw, K. van der Hem, and P. E. De Jong 1989. Antihypertensive effect of a 5-day infusion of atrial natriuretic factor in humans. Hypertension. 13:640-646.

73. Lowry, O. H., N. J. Rosebrough, A. L. Farr, and R. J. Randall. 1951. Protein measurement with the folin phenol reagent. J. Biol. Chem. 193:265-275.

74. Richman, R. A., G. S. Kopf, P. Hamet, and R. A. Johnson. 1980. Preparation of cyclic nucleotide antisera with thyroglobulin-cyclic nucleotide conjugates. J. Cyclic Nucleotide Res. 6:461-468.

75. Hamet, P., S. C. Pang, and J. Tremblay. 1989. Atrial natriuretic factor-induced egression of cyclic guanosine 3':5'-monophosphate in cultured vascular smooth muscle and endothelial cells. J. Biol. Chem. 264:12364-12369.

76. Peterson, G. L. 1977. A simplification of the protein assay method of Lowry et al. which is more generally applicable. Anal. Biochem. 83:346-356.

77. Gutkowska, J., J. Genest, G. Thibault, R. Garcia, P. Larochelle, J. R. Cusson, O. Kuchel, P. Hamet, A. De Lean, and M. Cantin. 1987. Circulating forms and radioimmunoassay of atrial natriuretic factor. In Endocrinology and Metabolism Clinics of North America, Vol. 16. M. Rosenblatt and J. W. Jacobs, editors. W. B. Saunders Company, Philadelphia. 183-198.

78. Tremblay, J., R. Gerzer, S. C. Pang, M. Cantin, J. Genest, and P. Hamet. 1986. ANF stimulation of detergent-dispersed particulate guanylate cyclase from bovine adrenal cortex. FEBS (Fed. Eur. Biochem. Soc.) Lett. 194:210-214.

79. Potier, M., and S. Giroux. 1985. Regulatory proteins (inhibitors or activators ) affect estimates of $M_{r}$ of enzymes and receptors by radiation inactivation-a theoretical model. Biochem. J. 226:797-801.

80. Beauregard, G., S. Giroux, and M. Potier. 1983. Target size analysis by radiation inactivation: a large capacity tube rack for irradiation in a Gammacell 220. Anal. Biochem. 132:362-364.

81. Beauregard, G., and M. Potier. 1984. Radiation inactivation of membrane proteins: molecular weight estimates in situ and after Triton X-100 solubilization. Anal. Biochem. 140:403-408.

82. Kempner, E. S., and W. Schlegel. 1979. Size determination of enzymes by radiation inactivation. Anal. Biochem. 92:2-10.

83. Kempner, E. S., and H. T. Haigler. 1982. The influence of low temperature on the radiation sensitivity of enzymes. J. Biol. Chem. 257:13297-13299.

84. Chinkers, M., D. L. Garbers, M. S. Chang, D. G. Lowe, H. Chin, D. V. Goeddel, and S. Schulz. 1989. A membrane form of guanylate cyclase is an atrial natriuretic peptide receptor. Nature (Lond.). 338:78-83.

85. Chomczynski, P., and N. Sacchi. 1987. Single-step method of RNA isolation by acid guanidinium thiocyanate-phenol-chloroform extraction. Anal. Biochem. 162:156-159.

86. Kurtz, T. W., M. Montano, L. Chan, and P. Kabra. 1989. Molecular evidence of genetic heterogeneity in Wistar-Kyoto rats: implications for research with the spontaneously hypertensive rat. Hypertension. 13:188-192.

87. Potier, M., C. Huot, C. Koch, P. Hamet, and J. Tremblay. 1991. Radiation-inactivation analysis of multidomain proteins: the case of particulate guanylate cyclase. In Methods in Enzymology, Vol. 195. R. A. Johnson and J. D. Corbin, editors. Academic Press, Orlando. 423-435.

88. Tremblay, J., C. Huot, C. Koch, and M. Potier. 1991. Characterization of the functional domains of the natriuretic peptide receptor/guanylate cyclase by radiation-inactivation. J. Biol. Chem. 266:8171-8175.

89. Becker-Andre, M., and K. Hahlbrock. 1989. Absolute mRNA quantification using the polymerase chain reaction (PCR). A novel approach by a PCR aided transcript titration assay (PATTY). Nucleic Acids. Res. 17:9437-9446.

90. Wang, A. M., M. V. Doyle, and D. F. Mark. 1989. Quantitation of mRNA by the polymerase chain reaction. Proc. Natl. Acad. Sci. USA. 86:9717-9721. 